\title{
Structural Performance Analysis of Cross Laminated Timber (CLT) Produced From Pine and Spruce Grown in Turkey
}

\author{
Abdullah Uğur BİRINCí1 ${ }^{*} \quad$ Hasan ÖZTÜRK ${ }^{2} \quad$ Cenk DEMIRKIR ${ }^{1} \quad$ Gürsel ÇOLAKOĞLU $^{1}$ \\ ${ }^{1 *}$ Karadeniz Technical University, Faculty of Forestry, Department of Forest Engineering, Kanuni Campus, Trabzon, Turkey \\ ${ }^{2}$ Karadeniz Technical University, Arsin Vocational School, Materials and Material Processing Technologies, Trabzon, Turkey
}

How to cite: Birinci, A.U., Öztürk, H., Demirkır, C. \& Çolakoğlu G. (2020). Structural Performance Analysis of Cross Laminated Timber (CLT) Produced From Pine and Spruce Grown in Turkey. J. Anatolian Env. and Anim. Sciences, 5(5), 819-824.

Atıf yapmak için: Birinci, A.U., Öztürk, H., Demirkır, C. \& Çolakoğlu G. (2020). Türkiye'de Yetiştirilen Sarıçam ve Doğu Ladininden Üretilen Çapraz Lamine Ahşap (CLT) Yapısal Performans Analizi. Anadolu Çev. ve Hay. Dergisi, 5(5), 819-824.

(iD: https://orcid.org/0000-0003-3273-3615

(iD) : https://orcid.org/0000-0002-5422-7556

(iD) : https://orcid.org/0000-0003-2503-8470

(iD) https://orcid.org/0000-0002-3795-281X

*Corresponding author's:

Abdullah Uğur Birinci

Karadeniz Technical University, Department

of Forest Industry Engineering, Kanuni

Campus, Trabzon, Turkey.

\: ugurbirinci@ktu.edu.tr

Mobile telephone: +90 (534) 2508387

Telephone $\quad:+90(462) 3771560$

Fax : +90(462) 3257499
Abstract: Wooden buildings with many advantages such as being lightness, durability, earthquake resistant, healthy, insulating, and esthetic are suitable for all kinds places especially earthquake zones. Cross-laminated timber (CLT) has increasingly become a viable alternative to other structural materials, mainly because of its excellent properties related to sustainability, energy efficiency, and speed of construction. This has resulted in the recent emergence of a significant number of CLT buildings constructed around the world. This is a study on determining the properties of CLT panels manufactured from wood species grown in Turkey and investigating of the structural behaviour and seismic resistant performance of them. Lumbers of $100 \mathrm{~mm}$ (width) x $50 \mathrm{~mm}$ (thickness) $\times 2400 \mathrm{~mm}$ (length) used in CLT manufacturing were obtained from eastern spruce (Picea orientalis L.) and scots pine (Pinus slyvestris) logs. Two replicate threelayered CLT panels of $2400 \mathrm{~mm} \times 2400 \mathrm{~mm} \times 150 \mathrm{~mm}$ in size were manufactured for each group. Density of the CLT panels was determined according to EN 323. The seismic resistant performance of the CLT shear walls was determined according to ASTM E 72 standard. CLT panels manufactured from scots pine gave higher seismic performance than those of CLT panels manufactured from spruce. The maximum load capacity of the walls increased with increasing the density values of the CLT panels.

Keywords: CLT (Cross Laminated Timber), structural behaviour performance, artificial neural network (ANN), scots pine, spruce.

\section{Türkiye'de Yetiştirilen Sarıçam ve Doğu Ladininden Üretilen Çapraz Lamine Ahşap (CLT) Yapısal Performans Analizi}

Öz: Hafif, dayanıklı, depreme dayanıklı, sağlıklı, yalıtkan ve estetik olması gibi pek çok avantaja sahip olan ahşap yapılar, deprem bölgeleri başta olmak üzere her türlü mekan için uygundur. Çapraz lamine ahşap (CLT), sürdürülebilir olması, enerji verimliliği ve yapım hızı ile ilgili mükemmel özellikleri nedeniyle, diğer yapısal malzemelere giderek artan bir şekilde daha uygun bir alternatif haline geldi. Bu, yakın zamanda dünya çapında inşa edilen önemli sayıda CLT binasının ortaya çıkmasıyla sonuçlanmıştır. Yapılan bu çalışma Türkiye'de yetişen ağaç türlerinden üretilen CLT panellerin özelliklerinin belirlenmesi, yapısal davranışı ve depreme dayanıklılık performanslarının incelenmesi üzerinedir. CLT imalatında kullanılan $100 \mathrm{~mm}$ (genişlik) x 50 mm (kalınlık) x 2400 mm (uzunluk) ölçülerindeki keresteler, Doğu Ladini (Picea orientalis L.) ve Sarıçam (Pinus slyvestris) tomruklarından elde edilmiştir. Her bir grup için 2400 $\mathrm{mm} \times 2400 \mathrm{~mm} \times 150 \mathrm{~mm}$ boyutlarında iki adet üç tabakalı CLT paneli üretilmiştir. CLT panellerinin yoğunluğu EN 323'e göre, perde duvarların sismik dayanıklılık performansı ise ASTM E 72 standardına göre belirlenmiştir. Sarıçamdan üretilen CLT paneller, ladinden üretilen CLT panellere göre daha yüksek sismik performans sağlamıştır. CLT panellerinin yoğunluk değerleri arttıkça duvarların maksimum yük taşıma kapasitesi artmıştır.

Anahtar kelimeler: CLT (Capraz Lamine Ahșap), yapısal davranıs performansı, yapay Sinir ağları, sarıçam. doğu ladin. 


\section{INTRODUCTION}

Timber constructions have undergone a revival of popularity over the last years; this positive trend is associated to a combination of several factors. Firstly, wood-based structural products generate fewer pollutants compared to the mineral-based building materials (e.g. steel and concrete) because are obtained from sustainable and renewable resources. Secondly, timber structural elements are prefabricated off-site and transported to the building location, where they are quickly assembled. Finally, the high strength-to-weight ratio of wood is a great advantage for structures erected in seismic-prone areas, because it limits the total mass of the buildings (Izzi et al., 2018). Engineered wood products, such as glued-laminated timber (glulam) beams and cross-laminated timber (CLT) panels, involve adhesive bonding and/or mechanical metallic fastening of timber to make large structural sections and building components (e.g. beams, columns, panels, walls, roofs) for construction applications. Furthermore, these engineered wood products are alternatives to common structural materials such as steel and concrete, and are consumed in large volumes worldwide (Sotayo et al., 2020).

CLT is a solid wood board made of timber a structural composite sheets with an orthogonal $\left(90^{\circ}\right)$ staggered assembly and is pressed by structural adhesives (FPInnovations, 2011). The use of Cross Laminated Timber (CLT) as a construction product has quickly grown in the last 15 years (Christovasilisa et al., 2020). The annual global volume production of CLT has seen exponential increases from production of $50,000 \mathrm{~m}^{3}$ in the year 2000, to $625,000 \mathrm{~m}^{3}$ in 2014 and an expected 3,000,000 $\mathrm{m}^{3}$ by 2025 (Dugmore et al., 2019). In recent years, Cross Laminated Timber (CLT) has been widely used for different types of buildings such as offices, commercial buildings, public buildings and multi-story residential complexes (Hashemi and Quenneville, 2020).

The cross lamination provides good dimensional stability to the product, makes prefabrication of long and wide panels possible, and provides higher splitting resistance in connection systems (Gagnon and Pirvu, 2011). Cross laminated timber provides an alternative to concrete and steel, with efficient structural properties and excellent environmental attributes. It is a viable option for multistory buildings and large-scale structures because of its light weight relative to concrete, high strength and stiffness relative to light-frame wood, and its ease of assembly attributed to a high degree of prefabrication (Hossain et al., 2016). Given that these panels are also the main lateral load-resisting elements, the seismic performance of the system considerably depends on their lateral strength and stiffness. Thus, extensive research on the seismic behavior of these structures has been initiated by many research groups around the world to investigate the feasibility of adopting timber panelized structures in very seismically active areas (Hashemi et al., 2020).

CLT passed a major milestone in North America in 2012 with the publishing of ANSI/APA PRG 320, a recently updated standard that defined product manufacturing and design specifications for producers and users (ANSI/APA, 2019). According to J. Elling of the APA - The Engineered Wood Association, Tacoma, WA. (personal communication, August 2019), there are currently six CLT manufacturers scattered around the U.S.; D.R. Johnson, Freres Lumber Co., Inc., International Beams, Katerra, SmartLam, Sterling Solutions, and Vaagen Timbers. (Scouse et al., 2020).

The adoption of cross-laminated timber in Central Europe, starting in Austria, has generated interest in using local resources to create CLT panels elsewhere in Europe (Sikora et al., 2016; Aicher et al., 2016), Asia (Okabe et al., 2014; Lu et al., 2018; Song and Hong, 2018), Australia and New Zealand (Iqbaì, 2015), North America (Mohamadzadeh and Hindman, 2015; Kramer et al., 2014; He et al., 2018; Crovella et al., 2019), and South America (Baño, 2016). Currently, three main softwoods species including Spruce-Pine-Fir, Southern-Pine-Fir and Douglas fir-Larch are used as the main raw materials for commercial production of CLT panels (FPInnovations, 2013., ANSI/APA, 2017). However, due to lack of softwoods species in some countries, many attempts have been focused on using local hardwood species to produce CLT panels (Srivaro et al., 2020) Also, CLT panels are made from different timber species that depend on local resources such as Kiri, Katsura, Sugi, Hinoki, Buna spruce pine (Europe and Canada) and Radiata pine (Australia and New Zealand) (Navaratnam et al., 2020).

When the literature analysis is examined, it was shown that every species from different locations used in CLT manufacturing gave different mechanical performance. Research has shown that lack of edge gluing and gaps can have an influence on the mechanical response of CLT (Gardner et al., 2020).

In this study the seismic performance of cross laminated timber produced from wood species grown in Turkey were investigated. Also, the current paper investigated the effect of gluing methods on the technological properties of CLT panels.

\section{MATERIALS AND METHOD}

Wood Materials and Manufacturing of CLT: In this experimental study, lumbers of $100 \mathrm{~mm}$ (width) x 50 mm (thickness) x $2400 \mathrm{~mm}$ (length) were obtained from eastern spruce (Picea orientalis L.) and scots pine (Pinus 
slyvestris) logs. The lumbers were oven-dried in a lumber dryer until to reach $8 \pm 3 \%$ equilibrium moisture content. All sides of the lumbers were planned to reach to the desired thicknesses and widths before manufacturing.

Polyurethane adhesive which has high resistance to water and temperature was used for CLT manufacturing (KLEIBERIT PUR Adhesive 506.0). It is D4 according to DIN/EN 204. Two different methods were applied in CLT panels manufacturing. In one, the adhesive was only applied to the top surfaces of the lumbers. The narrow edges of them were not glued (non-edge-gluing). In other method, the adhesive was applied to both of upper surfaces and the narrow edges of lumbers (edge-gluing). Adhesive applying processes on CLT panels are shown in Figure 1 for both methods. The adhesive was applied at a rate of 160 $\mathrm{g} / \mathrm{m}^{2}$ by using a roller glue spreader.

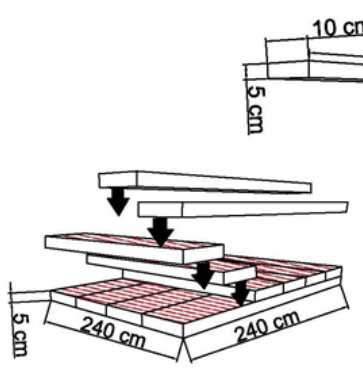

a)



b)
Figure 1. a) Non-edge gluing, b) Edge gluing (The shaded area shows the surfaces where gluing is applied).

Hydraulic cold press which can apply vertical clamping pressure and side clamping pressure as shown in Figure 2 was used for pressing of CLT panels. The panels were pressed under a vertical clamping pressure $(0.8$ $\left.\mathrm{N} / \mathrm{mm}^{2}\right)$ and side clamping pressure $\left(0,276-0,550 \mathrm{~N} / \mathrm{mm}^{2}\right)$ for $40 \mathrm{~min}$ at ambient temperature.

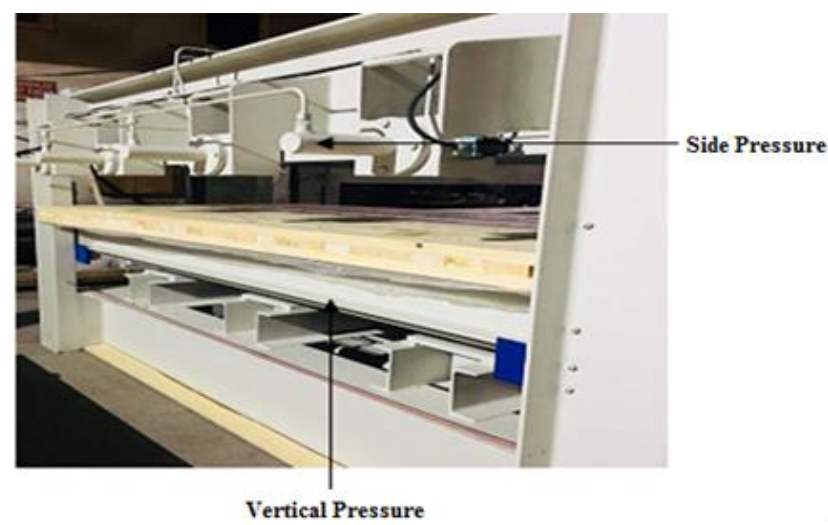

Figure 2. Hydraulic cold press.

In this study, two replicate three-layered CLT panels of $2400 \mathrm{~mm} \times 2400 \mathrm{~mm} \times 150 \mathrm{~mm}$ in size were manufactured for each group. Then the panels were conditioned at $65 \pm 5 \% \mathrm{RH}$ and $20 \pm 2{ }^{\circ} \mathrm{C}$ for 2 weeks prior to technological testing.

Testing Procedures: The seismic resistant performance of the CLT shear walls was determined according to ASTM E 72 standard. Maximum load capacity and maximum displacement were also detected for each group. A sketch of the test set-up with a specimen ready for testing is shown in Figure 3a (Popovski and Karacabeyli, 2012). CLT wall during the testing is shown in Figure 3b. CLT shear walls in platform-type construction consist of two parts: connections and CLT panels (Figure 3b) (Shahnewaz et al., 2019).

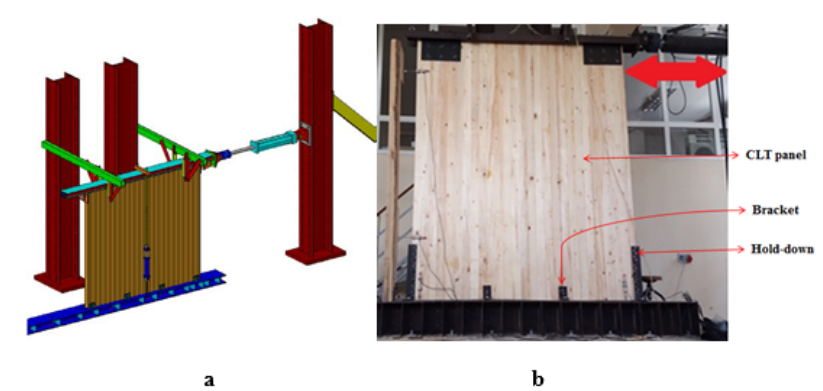

Figure 3. a) Sketch of the test setup used for CLT walls b) CLT wall during test.

The CLT wall analyses were carried out according to the ASTM E72 (2014) standard for displacements under loads of $354 \mathrm{~kg}, 712 \mathrm{~kg}$ and $1071 \mathrm{~kg}$. After the shear wall was loaded as specified to $354 \mathrm{~kg}, 712 \mathrm{~kg}$ and $1071 \mathrm{~kg}$ load it again to failure or until the total displacement of the panel becomes $100 \mathrm{~mm}$. The load was then loaded up to the maximum load that the shear wall could carry and the displacements at maximum load were determined.

Density of CLT panels were determined according to EN 323 (1993).

\section{RESULTS AND DISCUSSION}

The density of the panels was determined in accordance with relevant standard. The obtained values are given in Table 1..

Table 1. Density of CLT panels

\begin{tabular}{ccccc}
\hline \multirow{2}{*}{$\begin{array}{c}\text { Density } \\
\left(\mathbf{g r} / \mathbf{c m}^{3}\right)\end{array}$} & \multicolumn{2}{c}{ Scots pine } & \multicolumn{2}{c}{ Spruce } \\
\cline { 2 - 5 } & Non-edge gluing & Edge gluing & Non-edge gluing & Edge gluing \\
\hline $\mathbf{X}$ & 0,471 & 0,456 & 0,467 & 0,443 \\
$\mathbf{S}$ & 0,0137 & 0,0214 & 0,0313 & 0,0140 \\
\hline
\end{tabular}

According to Table 1, the density of CLT panels manufactured from scots pine logs is the higher than spruce.

The CLT wall groups were tested according to ASTM E 72 (2014) and some calculations were made for the seismic performance of the walls in the current study. 


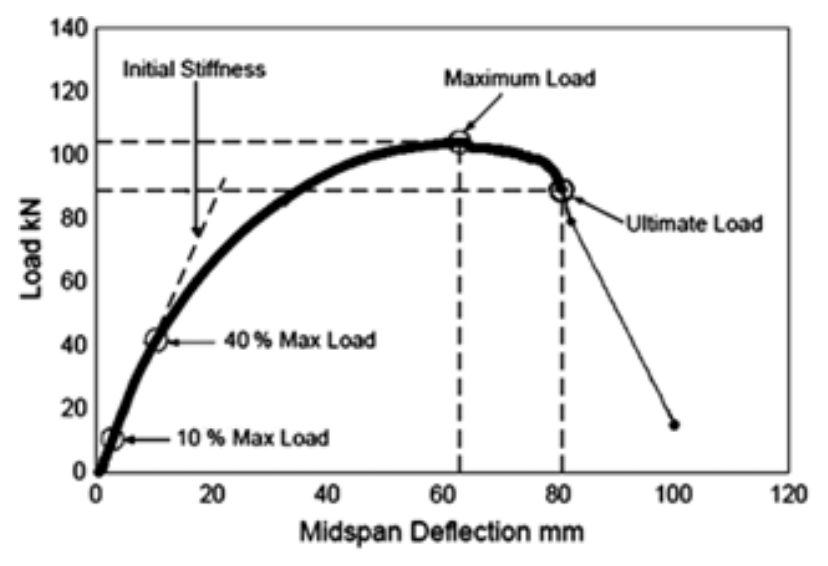

Figure 4. Analysis of a load-displacement curve (Pirvu 2008).

The following properties were calculated from this test, as illustrated in Figure 4:

- Initial stiffness, by selecting the points closest to $10 \%$ and $40 \%$ of the maximum load and fitting a straight line to the intervening points;

- Ultimate load, as $80 \%$ of the maximum load;

- Displacement at ultimate load; was identified based on the calculated ultimate load.

Figure 5 shows the response of the CLT walls tested under loading. Higher maximum load displacements at maximum load were obtained from scots pine (non-edge gluing) CLT walls. Spruce CLT wall groups were higher maximum load displacements values at maximum load than those of scots pine CLT wall groups.

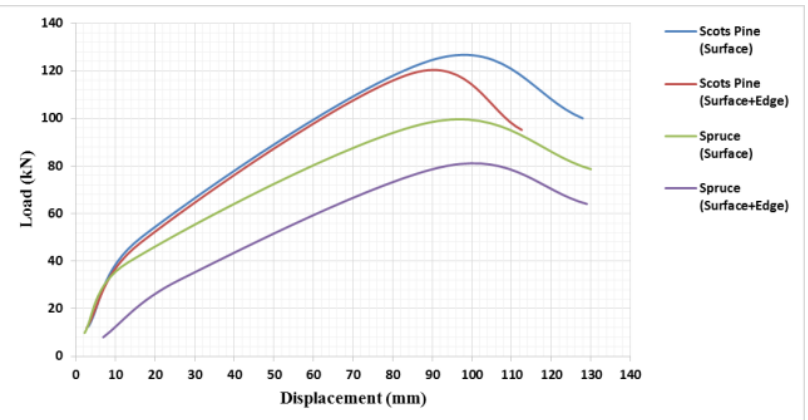

Figure 5. Load-displacement relationship for the test groups.

Table 2. Results of seismic resistant performance test.

\begin{tabular}{|c|c|c|c|c|c|c|}
\hline $\begin{array}{l}\text { Wood } \\
\text { Species }\end{array}$ & $\begin{array}{l}\text { Gluing } \\
\text { Method }\end{array}$ & $\underset{\operatorname{Load}(k N)}{\operatorname{Max} .}$ & $\begin{array}{c}\text { Max. } \\
\text { displacement } \\
(\mathrm{mm})\end{array}$ & $\begin{array}{l}\text { Stiffness } \\
(\mathbf{k N} / \mathbf{m m})\end{array}$ & $\begin{array}{c}\text { Ultimate } \\
\text { load }(k N)\end{array}$ & $\begin{array}{l}\text { Displacement } \\
\text { at ultimate } \\
\text { load (mm) }\end{array}$ \\
\hline \multirow{2}{*}{$\begin{array}{l}\text { Scots } \\
\text { pine }\end{array}$} & $\begin{array}{c}\begin{array}{c}\text { Non-edge } \\
\text { gluing }\end{array} \\
\end{array}$ & 125.09 & 90.94 & 2.81 & 100.07 & 127.96 \\
\hline & $\begin{array}{c}\text { Edge } \\
\text { gluing }\end{array}$ & 119.02 & 84,95 & 2.65 & 95.21 & 112.57 \\
\hline \multirow{2}{*}{ Spruce } & $\begin{array}{c}\text { Non-edge } \\
\text { gluing }\end{array}$ & 98.35 & 89.33 & 2.72 & 78.68 & 130.4 \\
\hline & $\begin{array}{c}\text { Edge } \\
\text { gluing }\end{array}$ & 80.09 & 93.78 & 1.25 & 64.07 & 128.99 \\
\hline
\end{tabular}

As shown in Figure 6, the main damages were found in the connecting elements at the end of the tests. It is similar to the literature. Previous researches indicated that CLT shear wall failure was mostly localized at the connections in a combination of sliding and rocking behavior (Shahnewaz et al. 2018; Gavric et al. 2015).

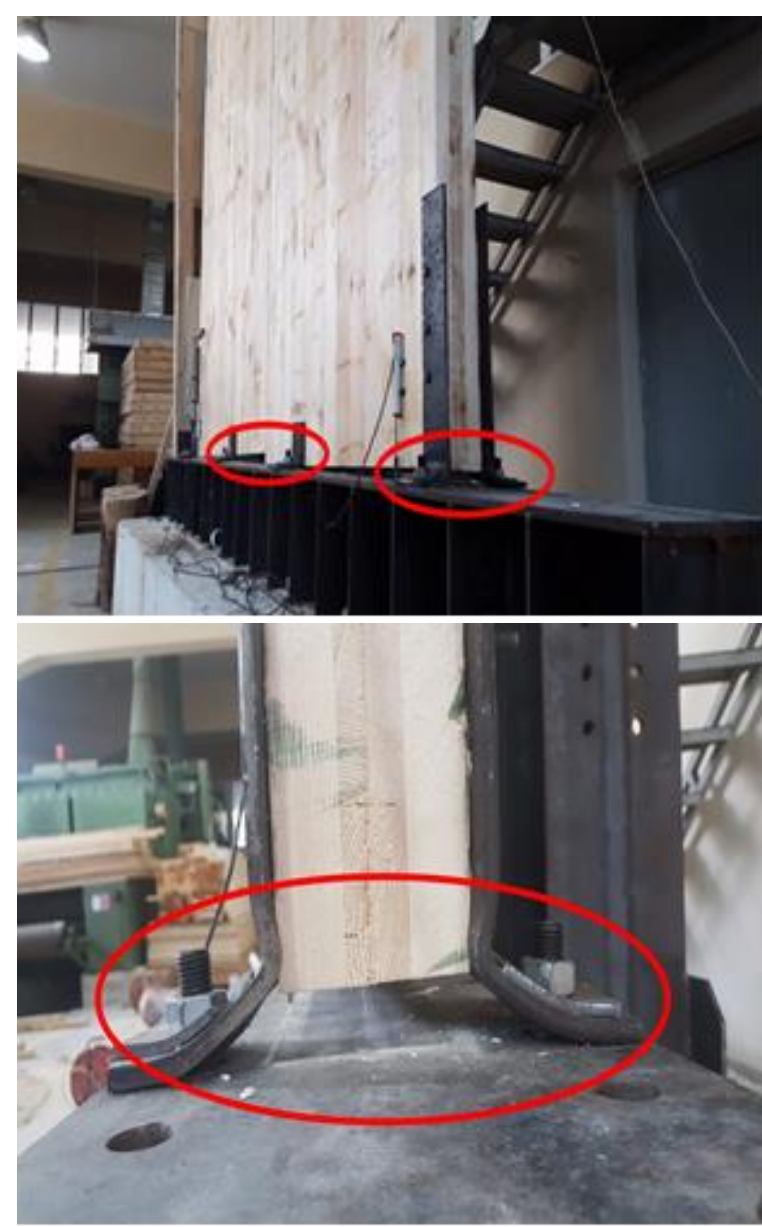

Figure 6. Failure modes of CLT shear walls.

Stiffness is one of the most important parameters for structural panels. If the panels used for sheathing material in a shear wall which have higher stiffness, they will be more resistant to earthquake loads (Demirkir and Colakoglu 2015). As shown in Table 2, CLT panels manufactured with scots pine (non-edge-gluing) showed the highest stiffness, whereas CLT panels manufactured with spruce (edge-gluing) showed the lowest stiffness value. In addition to stiffness, ductility which is defined as the ability to deform structures especially with the effect of the load, is also an important factor. The displacement values at ultimate load can be compared in determining the ductility properties of the walls. According to Table 2, CLT panels manufactured with spruce (non-edge-gluing) showed the highest displacement value at ultimate load, whereas CLT panels manufactured with scots pine (edgegluing) showed the lowest value. Gavric et al. (2015) were examined cyclic behavior of CLT wall systems and they found initial and plastic stiffness values between 0.47-0.96 $\mathrm{kN} / \mathrm{mm}, 2.82-5.77 \mathrm{kN} / \mathrm{mm}$, respectively. In this study, the stiffness values were found in between 1.25 and 2.81 $\mathrm{kN} / \mathrm{mm}$. Since CLT panels are rigid in comparison to their 
connections, the stiffness of CLT systems mostly depends on the connections (Shahnewaz et al. 2018).

When the effect of wood species on the maximum load carried by the walls is examined, the CLT walls manufactured from scots pine gave higher results than CLT walls manufactured from spruce (Table 2). The reason of this, scots pine has the highest density values (Table 1). It was stated that the lateral load resistance of a timber frame system depends on the rigidity of the timber, the sheathing material and the connecting elements used on the shear wall ( $\mathrm{Li}$ et al. 2007). The highest displacement value at ultimate load was obtained from the CLT shear walls manufactured from spruce. As can be seen from Table 2, the maximum load values and displacement value at ultimate load of non-edge-gluing CLT panels were higher than those of the edge-gluing CLT panels. The lateral resistance of shear walls is generally influenced by 4 factors which are stiffness, bending strength, resistance at break and ductility (Demirkir et al. 2019).

The current version of ANSI/APA PRG 320 (2018), the performance standard for CLT in North America, has no provisions for gaps in CLT, and it is the authors' understanding that the committee that oversees PRG-320 is now considering a limitation on gaps. Under the European standard (2015), gaps as large as $6 \mathrm{~mm}$ are acceptable between adjacent laminations within a layer. Since edge gluing is not required under either standard, it is not uncommon for small gaps to occur between edge joints during the manufacturing process (Gardner et al., 2020).

\section{CONCLUSION}

The effects of production factors (wood species, gluing method) of CLT panels manufactured from wood species grown in Turkey on seismic performance of the panels were investigated in this study. CLT panels manufactured from scots pine gave higher maximum load $(\mathrm{kN})$ and ultimate load $(\mathrm{kN})$ values than those of CLT panels manufactured from spruce. Generally, CLT panels manufactured from non-edge-gluing of lumbers gave higher seismic performance than those of CLT panels manufactured from edge gluing of lumbers. Therefore, it can be concluded that there is no need to glue the side surfaces which cause loss of labor, time and cost. It is thought that the results presented in this study can provide a basis for the use of CLT panels from wood species grown in Turkey, resulting to widespread of CLT panel whole Turkey.

\section{ACKNOWLEDGMENTS}

The authors acknowledge the financial support of this study by TUBITAK (The Scientific and Technical
Research Council of Turkey) (Project No: 2170081). This study was presented in ORENKO 2020 held by Karadeniz Technical University, Trabzon.

\section{REFERENCES}

Aicher, S., Hirsch, M. \& Christian, Z. (2016). Hybrid Cross-Laminated Timber Plates with Beech Wood Cross-Layers. Construction and Building Materials, 124, 1007-1018.

American Society for Testing and Materials (ASTM) E72. (2014). Standard Test Methods of Conducting Strength Tests of Panels for Building Construction, West Conshohocken, A, United States.

ANSI/APA PRG-320. (2017). Standard for PerformanceRated Cross- Laminated Timber, American National Standards Institute, USA.

ANSI/APA. (2019). Standard for performance-rated crosslaminated timber. PRG 320-2012. Tacoma, WA: APA The Engineered Wood Association.

APA-The Engineered Wood Association (2018). ANSI/APA PRG 320-2018 Standard for PerformanceRated Cross-Laminated Timber, Tacoma, WA: APAThe Engineered Wood Association

Baño, V., Godoy, D. \& Vega, A. (2016). Experimental and Numerical Evaluation of Cross-Laminated Timber (CLT) Panels Produced with Pine Timber from Thinnings in Uruguay. World Conf. Timber Eng. 2016 WCTE 2016, August 22-25.

Christovasilisa, I.P., Riparbelli, L., Rinaldin, G. \& Tamagnone, G. (2020). Methods for Practice-Oriented Linear Analysis in Seismic Design of Cross Laminated Timber Buildings. Soil Dynamics and Earthquake Engineering, 128, 105869.

Crovella, P., Smith, W. \& Bartczak, J. (2019). Experimental Verification of Shear Analogy Approach to Predict Bending Stiffness for Softwood and Hardwood CrossLaminated Timber Panels, Construction and Building Materials, 229, 116895.

Demirkir, C. \& Colakoglu, G. (2015). The Effect of Grain Direction on Lateral Nail Strength and Thermal Conductivity of Structural Plywood Panels, Maderas. Ciencia y tecnología, 17(3), 469-478.

Demirkir, C., Colakoglu, G. \& Karacabeyli, E. (2012). Effect of Manufacturing Factors on Technological Properties of Plywood From Northern Turkey And Suitability of Panels for Use in Shear Walls. Journal of structural engineering, 139(12), 04013002.

DIN/EN 204. (2001). Classification of Thermoplastic Wood Adhesives for Non-Structural Applications. German Institute for Standardisation (Deutsches Institut für Normung).

Dugmore, M., Nocetti, M., Brunetti, M., Naghizadeh, Z. \& Wessels, C. B. (2019). Bonding Quality of CrossLaminated Timber: Evaluation of Test Methods on 
Eucalyptus Grandis Panels, Construction and Building Materials, 211, 217-227.

EN 323. (1993) Wood-Based panels. Determination ofdensity. European Standards, Brussels.

European Committee For Standardization. (2015). EN 16351: Timber structures-Cross laminated timberRequirements, Brusssels, BEL.

Fortune, A. \& Quenneville, P. (2011). Feasibility Study of New Zealand Radiata Pine Cross-Laminated Timber. New Zealand Timber Design Journal, 19(3), 3-7.

FPInnovations. (2013). CLT Handbook, FPInnovations, BC.

FPInnovations. (2011). CLT Handbook: Cross-Laminated, FPInnovations, Quebec, Canada.

Gagnon, S. \& Pirvu, C. (2011). Cross laminated timber (CLT) handbook. FPInnovations, Vancouver, Canada.

Gardner, C., Davids, W.G., Lopez-Anido, R., Herzog, B., Edgar, R., Nagy, E., Berube, K. \& Shaler, S. (2020). The Effect of Edge Gaps on Shear Strength and Rolling Shear Modulus of Cross Laminated Timber Panels. Construction and Building Materials, 259, 119710.

Gavric, I., Fragiacomo, M. \& Cecotti, A. (2015c). Cyclic Behaviour of CLT Wall Systems: Experimental Tests and Analytical Prediction Model. Journal of structural engineering, 141(11), 04015034.

Hashemi, A. \& Quenneville, P. (2020). Large-Scale Testing of Low Damage Rocking Cross Laminated Timber (CLT) Wall Panels With Friction Damper. Engineering Structures, 206, 110166.

Hashemi, A., Bagheri, H., Yousef-Beik, S.M.M., Darani, F.M., Valadbeigi, A., Zarnani, P. \& Quenneville, P. (2020). Enhanced Seismic Performance of Timber Structures Using Resilient Connections: Full-Scale Testing and Design Procedure. Journal of structural engineering, 146(9), 04020180.

He, M., Sun, X. \& Li, Z. (2018). Bending and Compressive Properties of Cross-Laminated Timber (CLT) Panels Made From Canadian Hemlock. Construction and Building Materials, 185.

Hossain, A., Danzig, I. \& Tannert, T. (2016). CrossLaminated Timber Shear Connections with DoubleAngled Self-Tapping Screw Assemblies. Journal of structural engineering, 142(11), 04016099.

Iqbaì, A., (2015). Cross-laminated Timber for Building Structures, Branz Study Rep., SR336, 12.

Izzi, M., Casagrande, D., Bezzi, S., Pasca, D., Follesa, M. \& Tomasi, R. (2018). Seismic Behaviour of Cross Laminated Timber Structures: A state-of-the-art review. Engineering Structures, 170, 42-52.

Kramer, A., Barbosa, A.R. \& Sinha, A. (2014). Viability of Hybrid Poplar in ANSI Approvedcross-Laminated Timber Applications. Journal of Materials in Civil Engineering, 26(7), 06014009, DOI: 10.1061/(ASCE)MT.1943-5533.0000936
Li, J., Beall, F. C. \& Breiner, T.A. (2007). Analysis of racking of Structural Assemblies Using Acoustic Emission. Advances in Acoustic Emission. AEWG, AE Group, (6), 202.

Lu, Z., Zhou, H.Y. \& Hu, L.C. (2018). Effects of Surface Treatment and Adhesives on bond Performance and Mechanical Properties of Cross-Laminated Timber (CLT) Made From Small Diameter Eucalyptus Timber. Construction and Building Materials, 161, 9-15.

Mohamadzadeh, M. \& Hindman, D. (2015). Mechanical Performance of Yellow-Poplar Cross Laminated Timber. Rep. No. CE/VPI-ST-15-13, 44.

Navaratnam, S., Christopher, P.B., Ngo, T. \& Le, T.V. (2020). Bending and Shear Performance of Australian Radiata Pine Cross-Laminated Timber. Construction and Building Materials, 232, 117215.

Okabe, M., Yasumura, M., Kobayashi, K. \& Fujita, K. (2014). Prediction of Bending Stiffness and Moment Carrying Capacityof Sugi Cross-Laminated Timber. Journal of Wood Science, 60, 49-58.

Pirvu, C. (2008). Structural Performance of Wood Diaphragms with Thick Panels. Canadian Forest Service No. 13, Final report. FPInnovations Forintek, March.

Scouse, A., Kelley, S.S., Liang, S. \& Bergman, R., (2020). Regional and Net Economic Impacts of High-Rise Mass Timber Construction in Oregon. Sustainable Cities and Society, 61, 102154.

Shahnewaz, M., Alam, S. \& Tannert, T. (2018). Resistance of Cross-Laminated Timber Shear Walls for PlatformType Construction, Journal of Structural Engineering, ASCE ISSN, 0733-9445.

Sikora, K.S., McPolin, D.O. \& Harte, A.M. (2016). Effects of the Thickness of Cross-Laminated Timber (CLT) Panels made from Irish Sitka Spruce on Mechanical Performance in Bending and Shear. Construction and Building Materials, 116, 141-150.

Song, Y.J. \& Hong, S.I., (2018). Performance Evaluation of the Bending Strength of Larch Cross-Laminated Timber, Wood Res., 63, 105-116.

Sotayo, A., Bradley, D.F., Bather, M., Oudjene, M., ElHoujeyri, I. \& Guan, Z. (2020). Development and Structural Behaviour of Adhesive Free Laminated Timber Beams and Cross Laminated Panels. Construction and Building Materials, 259, 119821.

Srivaro, S., Tomad, J., Shi, J. \& Cai, J. (2020). Characterization of Coconut (Cocos Nucifera) Trunk's Properties and Evaluation of its Suitability to be Used as Raw Material for Cross Laminated Timber Production. Construction and Building Materials, 254, 119291. 